Kamtschatka. He gives a single instance, which, he says, "the natives speak of as a well-known fact, and that is, the stratagem they (the bears) have recourse to in order to catch the bareins, which are considerably too swift of foot for them. These animals keep together in large herds, and love to browse at the feet of rocks and precipices. The bear hunts them by scent till he comes in sight, when he advances warily, keeping above them, and concealing himself among the rocks as he makes his approaches, till he gets immediately over them, and nigh enough for his purpose. He then begins to push down with his paws pieces of rock among the herd below. This mancuvre is not followed by any attempt to pursue, until he has maimed one of the flosk, upon which a course immediately ensues, that proves successful, or otherwise, according to the hurt the barein receives. I cannot conclude this digression without observing that the Kamtschadales very thankfully acknowledge their obligations to the bears for what little advancement they have hitherto made either in the sciences or polite arts. They confess that they owe to them all their skill in physic and surgery; that by remarking with what herbs these antmals rub the wounds they have received, and what they have recourse to when sick and languid, they have become acquainted with most of the simples in use among them, either in the way of internal medicine or external application."

After this we are not surprised when we are told that the Kamtschadales receive instruction from the bears even in the "polite arts," and imitate in their dances the various attitudes and gestures of these animals. It seems that in the rôles of master and pupil the proverbial Savoyard and dancing bear would find matters reversed in Kamtscbatka.

Millbrook, Tuam, February 3

\section{J. Birmingham}

\section{Electric Railways}

Prof. Ayrton speaks as to the advantages obtainable from an electric system of railways, He says:- "The mass of the locomotive adds at least 50 per cent. to the horse-power absolutely necessary to propel the carriages along" (NATURE, vol. xxvii. p. 255). In short, he speaks of the weight of the ordinary locomotive as superfluous, and considers that " a far large number of passengers may travel at a greater speed and with less fear of danger than at present." Now, speaking practically, it is difficult to conceive of a train of carriages running sixty miles per hour without any massive locomotive in front. It would be easy enough to get up the requisite speed, but the train would certainly leave the road, there being nothing tending to keep the carriages steady, unless they were very heavy. The grip on the rails is directly as the weight of rolling stock, and it is generally found that the light coaches leave the road more readily than the modern heavy carriages. Of course the cant of the rails must not be neslected. I wish that Prof. Ayrton would favour NATURE with a few remarks on these points.

\section{The Channel Tunnel}

WiLL you allow me to correct an unfortunate slip of the pen in my article on "The Silver Streak and the Channel Tunnel" in the current number of the Contemporary Review? The rate of the progress of the French Channel Tunnel from the little village of Sangatte towards the English shores was, in November last, I8 yards per day and not "per week." At the present time the Beaumont and English boring machine is cutting the 7 -foot driftway at the rate of more than 20 metres per day, and has not arrived at the limit of its capacity.

Owens College, Manchester

\section{The Great Comet of 1882}

THE comet not having been visible to my naked eye during the last lunation, I was astoni.shed to find last night that (doubtless owing to its increasing altitude; and the clear, dark sky) its tail is still so visible, quite distinctly, though very faint. I saw it best with a pair of field-glasses, aperture 2.05 inches, power 4 ; with which it reached to $\nu^{2}$ Canis Majoris, and was therefore $5 \frac{1^{\circ}}{2}$ long; unless part was really a wisp of the Milky Way: undoubtedly the greater part was the comet. Its axis (which was nearer the north than the south edge) was straight for $3 \frac{1}{2}^{\circ}$, and then appeared to curve southwards somewhat. It; south edge was straight, but its north edge, which was more definite, was convex. Its width was nearly $2^{\circ}$. I could not detect any of the definite features which were so remarkable formerly.
The tail was nearly as long with the naked eye. Its head and two neighbouring stars were plainly visible to the naked eye as one star. One of these stars (Lalande 12,056 ) was decidedly brighter than the comet's head, which would be about of the $7^{\text {th }}$ mag.

With a $4 \frac{1}{4}$-inch refractor the head continues elongated. With a power of 20, its major axis (which was in the direction of the tail) was $16^{\prime}$ lony, and its minor axis $1 \mathbf{I}^{\prime}$. With a power of $3^{8}$ it was $13^{\prime}$ by $82^{\prime}$.

Sunderland, January $3 \mathrm{I}$

\section{Meteor of November I7}

IT is perhaps rather late to revert to the auroral cloud of November 17 , but I am away from home, and have only now gained the requisite information. The path which $\mathrm{I}$. ventured to assign for it in your issue of November 30 , from a digest of the printed reports, as compared with my own observations at Clevedon, proves to have been substantially correct. The cloud passed in the zenith at Brussels, as witnessed by M. Montigny, an eminent Belgian savant; and at Laon it was seen to the northward, as it were, gliding round the upper edge of the great main arch of the aurora. The actual elevation above the surface of the earth may therefore, without much risk of error, be considered as between forty and forty-five miles.

Montreux, February 3

Stephen H. Saxby

\section{The Sea Serpent}

LIKE your correspondent, Mr. Sidebotham (in NATURE, vol. xxvii. p. 315), I have frequently seen a shoal of porpoises in Llandudno Bay, as well as in other places, and on the occasion referred to by Mr. Mott, in NATURE, vol. xxvii. p. 293, the idea of porpoises was at first started but immediately aban. doned. I will venture to suggest that no one has seen a shoal of these creatures travel at the rate of from twenty-five to thirty miles an hour. I have seen whales in the ocean, and large flocks of sea-birds, such as those of the eider duck, skimming its surface; but the strange appearance seen at Llandudno on September 3 was not to be accounted for by porpoises, whales, birds, or breakers, an opinion which was shared by all present.

\section{Welford Place, Leicester, February 2}

WILLIAM BARFOOT

IN the summer of $188 \mathrm{I}$ I was staying for some weeks at Veulettes, on the coast of Normandy. While there, on several occasions, several members of my party, as well as myself, saw, at a distance of three or four miles out at sea, what had the appearance of a huge serpent. Its length was many times that of the large.st steamer that ever passed, and its velocity equally exceeded that of the swiftest. What seemed its head was lifted and lowered, and sometimes appeared to show signs of an open mouth. The general appearance of the monster was almos exactly similar to that of the figure in your correspondent's letter published on the $25^{\text {th }}$ ult. Not the slightest appearance of discontinuity in its structure could be perceived by the eye although it seemed incredible that any muscular mechanism could really drive such an enormous mass through the water with such a prodigious velocity. I carefully watched all that any of $\mathrm{us}$ caught sight of, and one day, just as one of these serpent forms was nearly opposite our hotel, it instantaneously turned through a right angle, but instead of going forward in the new direction of its length, proceeded with the same velocity broadside forward. With the same movement it resolved itself into a flock of birds.

We often saw the sea-serpent again without this resolution being effected, and, knowing what it was, could with difficulty still perceive that it was not a continuous body; thus having a new illustration of Herschel's remark, that it is easier to see what has been once discovered than to discover what is unknown. Possibly this experience may afford the solution of your correspondent's difficulty. W. STEADMAN ALDIS

College of Physical Science, Newcastle-upon-Tyne, Feb. 3

\section{Natural Enemies of Butterflies}

IT would be very interesting to ascertain what testimony can be brought forward to show that the Rhopalocera are commonly the prey of insect-eating birds. The return of a gentleman who has been collecting butterflies and studying their transformations 